\title{
Sibcatie gowreal
}

Jurnal Ilmiah Bioang Sosial, Tkonomi, Budaya, Tekuologi, dan Pendidikan

\section{ANALISIS KESULITAN BELAJAR MATEMATIKA PADA PEMBELAJARAN DARING SISWA KELAS III DI SDN PORIS GAGA O6 KOTA TANGERANG}

\author{
${ }^{1}$ Melani Iknesya Siskanti, ${ }^{2}$ Candra Puspita Rini, ${ }^{3}$ Aam Amaliyah \\ 1,2,3 Universitas Muhammadiyah Tangerang \\ Email: ${ }^{1}$ melaniiknesyasiskanti.11@gmail.com, ${ }^{2}$ candrapuspitarini@gmail.com, \\ 3aam.umt@gmail.com
}

\begin{abstract}
Abstrak
Penelitian ini bertujuan untuk mengetahui kesulitan-kesulitan belajar yang dialami siswa dan mengetahui faktor-faktor yang mempengaruhi kesulitan belajar yang dialami siswa. Penelitian ini merupakan penelitian kualitatif deskripstif, subjek penelitian ini adalah siswa kelas 3 SDN Poris Gaga 06 Kota Tangerang. Teknik pengumpulan data dilakukan dengan metode observasi, wawancara, dan tes matematika. Berdasarkan hasil penelitian bahwa kesulitan belajar matematika dapat dilihat dari kecenderungan rendahnya hasil latihan soal. Kesulitan yang dialami siswa dalam belajar matematika yaitu kesulitan dalam memahami soal, kesulitan dalam melakukan operasi hitung pembagian, kesulitan dalam memecahkan masalah matematika. Faktor yang mempengaruhi kesulitan belajar adalah faktor internal diantaranya yaitu, lamban dalam memahami materi, faktor kejiwaan berupa perasaan tidak suka terhadap mata pelajaran matematika sehingga menyebabkan sikap negatif tidak memperhatikan ketika guru menjelaskan materi dan tidak aktif saat pembelajaran, dan faktor fisiologis berupa siswa merasa kebingungan saat pelajaran matematika. Faktor eksternal meliputi metode yang digunakan masih belum bervariasi yaitu hanya memberikan tugas dan tidak melibatkan siswa ikut terlibat aktif secara daring dalam pembelajaran.
\end{abstract}

Kata kunci: kesulitan belajar, matematika, faktor-faktor penyebab

\begin{abstract}
This study aims to determine the learning difficulties experienced by students and determine the factors that influence the learning difficulties experienced by students. This research is descriptive qualitative research, the subject of this research is the 3rd grade students of SDN Poris Gaga 06 Tangerang City. Data collection techniques were carried out using observation, interviews, and math tests. Based on the results of the study that learning difficulties in mathematics can be seen from the low tendency of the results of practice questions. The difficulties experienced by students in learning mathematics are difficulties in understanding problems, difficulties in performing arithmetic division operations, difficulties in solving mathematical problems. Factors that affect learning difficulties are internal factors including being slow in understanding the material, psychological factors in the form of feelings of dislike for mathematics subjects, causing negative attitudes of not paying attention when the teacher explains the material and being inactive during learning, and physiological factors in the form of students feeling confused when math. External factors include the methods used are still not varied, namely only giving assignments and not involving students being actively involved online in learning.

Keywords: learning difficulties, mathematics, causal factors.
\end{abstract}

\section{PENDAHULUAN}

Menurut Husamah dkk (2018) "Belajar pada hakikatnya yaitu merupakan suatu proses usaha yang yang dilakukan individu secara sadar untuk memperoleh tingkah laku tertentu"(h. 5). Berdasarkan pengertian tersebut bahwa belajar adalah termasuk aktivitas mental dan psikis yang berlangsung dalam interaksi aktif dengan lingkungan. Serta dapat 
menghasilkan perubahan dalam pengetahuan dan pemahaman, keterampilan serta nilai-nilai, dan sikap. Semakin sering belajar maka akan semakin meningkat juga tingkat perubahan seseorang. Dengan belajar selain memperoleh perubahan pada tingkah laku, juga mendapatkan pengetahuan serta wawasan yang baru.

Definisi tentang kesulitan belajar pertama kali dikemukakan oleh Abdurrahman (2019) bahwa "Kesulitan belajar adalah suatu gangguan dalam satu atau lebih dari proses psikologis dasar yang mencakup pemahaman dan penggunaan bahasa ujaran atau tulisan" (h. 2). Berdasarkan pengertian tersebut bahwa kesulitan belajar merupakan suatu kondisi dimana siswa tidak dapat belajar dengan baik. Disebabkan karena adanya gangguan, baik berasal dari faktor internal siswa maupun faktor eskternalnya. Adapun pada kesulitan belajar sering terjadi bersamaan dengan kondisi-kondisi lain.

Selanjutnya The National Joint Committee For Learning Disabilities (NJCLD) dalam buku Abdurrahman (2019) mengemukakan "Kesulitan belajar yaitu menunjuk pada sekelompok kesulitan yang dimanifestasikan dalam bentuk kesulitan yang nyata dalam kemahiran dan penggunaan kemampuan mendengarkan, bercakap - cakap, membaca, menulis, menalar, atau kemampuan dalam bidang studi matematika" (h. 3). Definisi ini menekankan bahwa kesulitan belajar merupakan suatu kondisi ketidakmampuan yang nyata pada orang-orang yang memiliki sistem saraf yang cukup, dan kesempatan untuk belajar yang cukup pula. Kondisi dalam kesulitan belajar ini dapat berpengaruh terhadap harga diri, pendidikan, pekerjaan, sosialisasi dan aktivitas kehidupan sehari-hari. Dengan adanya kesulitan belajar siswa dapat mengetahui letak kekurangannya dalam mengalami proses pembelajaran.

Abdurrahman dalam kutipan Kusmanto (2003) mengungkapkan bahwa rendahnya hasil belajar matematika dimungkinkan beberapa kekeliruan umum dilakukan siswa berkesulitan belajar matematika yaitu dalam simbol, nilai tempat, perhitungan, penggunaan proses yang keliru dan tulisan yang tidak dapat dibaca.

Sedangkan menurut Lerner (2003) kesalahan umum yang dilakukan oleh siswa yang berkesulitan dalam belajar matematika adalah kurangnya pemahaman tentang simbol, nilai tempat, perhitungan, serta penggunaan proses yang keliru dan tulisan yang tidak terbaca. Sedangkan kesalahan siswa dalam mengerjakan matematika merupakan kesalahan dasar, kesalahan dalam pemahaman soal, kesalahan dalam pengambilan keputusan dan kesalahan dalam hal perhitungan, sehingga dapat membuat rendahnya hasil belajar siswa (Arsyad dan Hakim, 2019, h. 3).

Menurut Ally (2004) berpendapat bahwa pembelajaran daring adalah proses pembelajaran yang menggunakan internet untuk mengakses materi, untuk berinteraksi dengan materi, instruktur dalam pembelajar lain, untuk mendapatkan dukungan selama proses pembelajaran dengan tujuan untuk memperoleh pengetahuan, menciptakan pemahaman dan untuk berkembang dari pengalaman belajar (Sudarsana dkk, 2020, h. 39). Berdasarkan pengertian tersebut dapat diambil kesimpulan bahwa pembelajaran daring merupakan pembelajaran yang dilakukan tidak tatap muka antara guru dan siswa. Pada 


\section{Sibatile Jocurnal}

Jurnal Ilmiah Bidang Sosial, Ekonomi, Budaya, Tekuologi, dan Pendidikan

proses pembelajaran daring lebih sering menggunakan jaringan internet. Dengan mengakses jaringan internet dapat digunakan untuk mengakses materi pembelajaran, berinteraksi dengan guru ataupun siswa, dan berdiskusi dengan siswa lainnya melalui media daring (online). Dari adanya pembelajaran daring secara tidak langsung kita dapat terhindar dari virus Covid - 19 dan juga sudah menerapkan peraturan jaga jarak antara satu dan yang lainnya.

Selanjutnya Dewi (2020) menjelaskan dengan adanya "Pembelajaran daring siswa akan memiliki keleluasaan waktu untuk belajar, dapat belajar kapanpun dan dimanapun. Siswa dapat berinteraksi dengan guru menggunakan beberapa aplikasi seperti google classroom, video converence, telepon atau live chat, zoom maupun melalui whatsapp group" (h. 56). Berdasarkan pengertian tersebut pembelajaran daring adalah suatu pembelajaran yang memiliki keluasan waktu karna tidak adanya batasan untuk mengakses materi yang sedang dipelajari. Pembelajaran daring juga dilaksanakan secara tidak tatap muka, dan dapat dilakukan dimanapun dan kapanpun. Selama proses pembelajaran yang dilakukan secara daring (online) ini siswa dapat mengakses beberapa aplikasi/platform pembelajaran yang sudah disediakan oleh pihak sekolah untuk berinteraksi dengan guru atau siswa lainnya. Seperti aplikasi whatsapp group, telepon, video conference, zoom, google classroom.

\section{METODE}

Dalam penelitian ini menggunakan pendekatan kualitatif dengan jenis metode penelitian deskriptif kualitatif. Hal ini dilakukan agar peneliti dapat mendeskripsikan secara jelas dan rinci serta mendapat data yang mendalam. Menurut Sugiyono (2016) dalam bukunya mengemukakan "Penelitian kualitatif adalah metode penelitian yang berlandaskan pada filsafat postpositivisme, digunakan untuk meneliti pada kondisi obyek yang alamiah, (sebagai lawannya adalah eksperimen) dimana peneliti adalah sebagai instrumen kunci, teknik pengumpulan data secara triangulasi (gabungan), analisis data bersifat induktif/kualitatif, dan hasil penelitian kualitatif lebih menekankan makna dari pada generalisasi" (h. 9).

Peneliti disini bertindak sebagai instrumen penelitian sekaligus merupakan perencana, pelaksana, pengumpulan data, penganalisis, dan pada akhirnya sebagai pelapor penelitian. Adapun kesulitan belajar siswa yang diukur pada penelitian ini terdiri dari tiga aspek, yaitu:

1) Kesulitan dalam memahami soal

2) Kesulitan dalam memahami operasi hitung (matematika).

3) Kesulitan dalam memecahkan masalah

\section{HASIL PEMBAHASAN}

\section{Isi Hasil Pembahasan}

Penelitian dengan judul "Analisis Kesulitan Belajar Matematika pada Pembelajaran Daring Siswa kelas III dalam pembelajaran Matematika di SDN Poris Gaga 06 Kota Tangerang" merupakan sebuah penelitian yang dilakukan untuk mengetahui tingkat 
kesulitan belajar siswa dalam pembelajaran Matematika selama pembelajaran daring berlangsung. Pada data hasil penelitian mengenai kesulitan belajar matematika siswa kelas III di peroleh melalui observasi, hasil tes yang nantinya akan dianalisis secara kualitatif dan wawancara dengan wali kelas III dan juga kepada siswa kelas IIIB. Dengan subjek penelitian yaitu 9 orang siswa.

\section{Analisis Data Hasil Tes Kesulitan Belajar Matematika Siswa Kelas III}

Pada penelitian ini tes kesulitan belajar matematika dilaksanakan setelah pokok bahasan selesai dibahas dan dipelajari. Tes tersebut dimaksudkan untuk mengetahui kesulitan belajar matematika siswa pada pembelajaran Matematika. Setiap tes mengacu pada indikator kesulitan belajar yang akan diteliti yaitu Kesulitan dalam memahami soal, Kesulitan dalam melakukan operasi hitung matematika (Pembagian), Kesulitan dalam memecahkan masalah. Data akan dianalisis sesuai dengan teknik analisis data yang telah ditentukan di bab III. Berikut ini dijelaskan beberapa data dan jenis kesulitan siswa yang ditemukan oleh peneliti:

Tabel 4.1

Rekapitulasi Hasil Tes Kesulitan Belajar Matematika Siswa Kelas III :

\begin{tabular}{|l|l|c|}
\hline No. & \multicolumn{1}{|c|}{ Indikator } & Frekuensi \\
\hline 1. & Kesulitan dalam memahami soal & 3 \\
\hline 2. & $\begin{array}{l}\text { Kesulitan dalam melakukan operasi hitung } \\
\text { matematika (Pembagian) }\end{array}$ & 3 \\
\hline 3. & Kesulitan dalam memecahkan masalah & 3 \\
\hline \multicolumn{2}{|c|}{ Jumlah } & $\mathbf{9}$ \\
\hline
\end{tabular}

Analisis data hasil tes dan wawancara kesulitan belajar matematika siswa kelas $\mathbf{V}$ pada pembelajaran Matematika berdasarkan subyek penelitian dan indikator kesulitan belajar

Kesulitan belajar matematika yang diukur dalam penelitian ini terdiri dari tiga indikator kesulitan belajar yaitu: Kesulitan dalam memahami soal, Kesulitan dalam melakukan operasi hitung matematika (Pembagian), Kesulitan dalam memecahkan masalah. Berdasarkan hasil penelitian diperoleh 5 soal kesulitan belajar matematika yang berbentuk uraian yang mencakup pada indikator kesulitan belajar matematika. Hal ini membuktikan bahwa siswa kemungkinan besar terindikasi mengalami kesulitan belajar. Berikut ini dijelaskan beberapa data dan jenis kesulitan siswa yang ditemukan oleh peneliti:

\section{Subjek 1:}

Berdasarkan hasil tes yang sudah dilakukan kepada subjek 1, didapatkan ringkasan data hasil tes kemampuan berpikir kritis seperti pada Tabel 1. 


\section{Sibcitile Jowrmal}

Jurnal Ilmiah Bioang Sosial, Thonomi, Budaya, Tekuologi, dan Pendidikan

Indikator Kesulitan Belajar

Kesulitan Memahami Soal

\section{Uraian}

S1 pada soal no. 1 siswa yang mengalami kesulitan pada indikator kesulitan dalam memahami soal dalam menyelesaikan soal tingkat kesulitannya masih tergolong rendah. S1 pada soal no. 2 menunjukkan bahwa siswa yang mengalami kesulitan pada indikator kesulitan dalam memahami soal dalam menyelesaikan soal tingkat kesulitannya masih tergolong rendah.

Kesulitan Memahami Operasi Hitung S1 pada soal no. 3 siswa yang mengalami kesulitan pada indikator kesulitan melakukan operasi hitung dalam menyelesaikan soal cerita tingkat kesulitannya masih tergolong rendah.

Kesulitan Memecahkan Masalah $\quad$ S1 pada soal no. 4 siswa yang mengalami kesulitan pada indikator kesulitan memecahkan masalah dalam menyelesaikan soal tingkat kesulitannya masih tergolong rendah.

S1 pada soal no. 5 siswa yang mengalami kesulitan pada indikator kesulitan memecahkan masalah dalam menyelesaikan soal cerita tingkat kesulitannya masih tergolong rendah.

Berdasarkan transkip wawancara yang telah dilakukan kepada subjek 1, terkait dengan pengalian informasi sebagaimana diuraikan di atas, maka diperoleh ringkasan hasil wawancara kemampuan berpikir kritis, seperti pada tabel 2.

Tabel 2 Ringkasan hasil wawancara subjek 1 pada indikator kesulitan belajar matematika

\begin{tabular}{ll}
\hline Indikator Kesulitan Belajar & \multicolumn{1}{c}{ Uraian } \\
\hline Kesulitan Memahami Soal & S1 mampu menyebutkan yang diketahui \\
& dalam soal dan juga mampu menjelaskan \\
& soal tersebut dengan bahasanya sendiri. Hal \\
& ini berarti TR mampu mengisi tentang soal \\
& bilangan dan nilai tempat dengan benar. \\
\hline & S1 mampu menjawab pertanyaan tersebut \\
& dengan bahasanya sendiri. Hal ini berarti \\
\hline
\end{tabular}


TR mampu mengisi tentang soal nilai tempat dengan benar.

Kesulitan Memahami Operasi Hitung S1 mampu memberikan pendapat tentang materi operasi hitung, dan pendapat mengenai soal pada indikator kesulitan melakukan operasi hitung.

Kesulitan Memecahkan Masalah $\quad$ S1 mampu mencari informasi sendiri pada saat pembelajaran daring.

S1 mampu menjelaskan dengan baik langkah penyelesaian yang sudah ditemukan pada soal nomor 5 dan juga mampu menentuka suatu tindakan terhadap suatu argumen sesuai dengan pernyataan dengan alasan yang sesuai.

\section{Subjek 2}

Tabel 3 Paparan Data Hasil Tes Kesulitan Belajar Matematika.

\begin{tabular}{ll}
\hline Indikator Kesulitan Belajar & Uraian \\
\hline Kesulitan Memahami Soal & S1 pada soal no. 1 siswa yang mengalami \\
& kesulitan pada indikator kesulitan dalam \\
& memahami soal dalam menyelesaikan soal \\
& tingkat kesulitannya masih tergolong \\
& sedang. \\
& S1 siswa yang mengalami kesulitan pada \\
& indikator kesulitan dalam memahami soal \\
& dalam menyelesaikan soal tingkat \\
& kesulitannya masih tergolong sedang. \\
\hline Kesulitan Memahami Operasi Hitung & S1 pada soal no. 3 yang mengalami \\
& kesulitan pada indikator kesulitan \\
& melakukan operasi hitung dalam \\
& menyelesaikan soal cerita tingkat \\
& kesulitannya tergolong sangat rendah. \\
\hline Kesulitan Memecahkan Masalah & S1 pada soal no. 4 siswa yang mengalami \\
& kesulitan pada indikator kesulitan \\
& memecahkan masalah \\
& menyelesaikan soal tingkat kesulitannya \\
& masih tergolong rendah. \\
\hline & S1 pada soal no. 5 siswa yang mengalami \\
& kesulitan pada indikator kesulitan \\
\hline
\end{tabular}




\section{Sibatile Jocurnal}

Jurnal Ilmiah Bioang Sosial, Tkonomi, Budaya, Tekuologi, dan Pendidikan

memecahkan

masalah

dalam

menyelesaikan soal tingkat kesulitannya

masih tergolong rendah.

\section{KESIMPULAN DAN SARAN \\ Kesimpulan}

Berdasarkan hasil penelitian analisis data dan pembahasan hasil penelitian tentang kesulitan belajar siswa dalam pembelajaran Matematika di SDN Poris Gaga 06 Kota Tangerang, maka dapat disimpulkan bahwa siswa pada kategori tingkat kesulitannya yang tergolong masih rendah, mampu menyelesaikan soal dengan baik yang terdapat pada semua indikator. Hal tersebut ditunjukkan dengan siswa mampu memahami soal dengan baik, mampu menyelesaikan bilangan operasi hitung, dan mampu memecahkan masalah tentang soal cerita yang berkaitan pada cara pembagian bersusun. Selanjutnya, siswa pada kategori tingkat kesulitannya yang tergolong masih sedang. Hal tersebut ditunjukkan dengan siswa mampu memahami soal yang berkaitan dengan indikator satu, dan sebagain siswa yang dapat menyelesaikan soal tes tentang operasi hitung dan memecahakn masalah yang ada pada soal tes kesulitan belajar matematika. Siswa pada kategori dalam tingkat kesulitan yang tergolong sangat tinggi. Hal tersebut ditunjukkan dengan siswa belum sepenuhnya mampu dalam mengerjakan soal tes kesulitan belajar matematika dengan baik sesuai dengan kriteria pada indikator. Siswa hanya mampu memenuhi satu indikator saja. Pada penelitian ini mayoritas siswa masih rendah tingkat berpikir kritisnya dalam materi matematika dikarenakan siswa masih kesulitan dalam menjawab dan menyelesaikan soal-soal Matematika, dan juga pemahaman siswa terhadap pembelajaran Matematika masih belum baik. Siswa sulit diajak untuk berpikir lebih kritis dalam memecahkan soal-soal Matematika. Cara berpikir siswa dinilai masih rendah karena siswa dalam pembelajaran cenderung hanya menerima materi yang diajarkan, tanpa mau menelaah lebih lanjut dan kurangnya pemahaman mendalam terhadap materi. Hal ini dikarenakan adanya beberapa faktor yang mempengaruhi kesulitan belajar matematika siswa yaitu terdiri dari faktor internal peserta didik dan faktor eksternal. Faktor internal yaitu meliputi faktor intelektual berupa lamban dalam memahami materi dan belum menguasai kemampuan prasyarat, faktor kejiwaan berupa perasaan tidak suka terhadap mata pelajaran matematika sehingga menyebabkan sikap negatif tidak memperhatikan ketika guru menjelaskan materi dan tidak aktif saat pembelajaran, dan faktor fisiologis berupa siswa merasa kebingungan saat pelajaran matematika. Faktor eksternal meliputi metode yang digunakan masih belum bervariasi yaitu hanya memberikan tugas dan tidak melibatkan siswa ikut terlibat aktif secara daring dalam pembelajaran.

\section{Saran}

\section{Bagi Guru}

Mengingat pentingnya penguasaan matematika dengan baik untuk diterapkan dalam kehidupan sehari-hari guru sebaiknya mengajarkan matematika dengan bervariasi yang 
disesuaikan dengan teori belajar matematika sehingga tidak hanya menggunakan metode ceramah. Variasi mengajar guru juga disertai penggunaan media dan alat peraga yang dapat meningkatkan antusias siswa dalam belajar matematika dan lebih membantu siswa dalam memahami konsep atau rumus matematika.

\section{Bagi Siswa}

Siswa hendaknya memiliki sikpa positif dan bersungguh-sungguh serta lebih aktif dalam pembelajaran matematika misalnya aktif bertanya saat menemui kesulitan dalam memahami materi yang disampaikan guru. Selain itu, siswa juga hendaknya latihan soal bahka ketika sedang belajar dengan orang tua dirumah dan siswa sebaiknya lebih teliti lagi dalam mengerjakan soal matematika agar kesulitan belajar matematika dapat dikurangi.

\section{Bagi Orang Tua}

Sebagai orang tua walaupun sedang dimasa pandemi seperti sekarang ini, hendaknya dapat memahami sifat anak sehingga akan lebih mudah untuk mendukung keinginan belajarnya dan mendorong sikap positif anak agar antusias dalam mempelajari matematika. Orang tua berperan serta untuk meyakinkan anak agar dapat menyukai mata pelajaran matematika dan anak tidak lagi menganggap matematika adalah mata pelajaran yang sulit.

\section{Bagi Peneliti Lain}

Hasil penelitian ini dapat dikembangkan dengan penelitian yang serupa sehingga dapat ditemukan upaya dalam mengatasi kesulitan belajar matematika lain.

\section{DAFTAR PUSTAKA}

Abdurrahman, M. (2019). Anak Berkesulitan Belajar. Jakarta: PT. Rineka Cipta.

Arsyad, R., \& Hakim, A. (2019). Diagnosis Kesulitan Penyelesaian Soal Matematika Pokok Bahasan Pecahan pada Siswa SD Muhammadiyah 2 Kota Sorong. Jurnal Ilmu Kependidikan, 8 No. 1, 3.

Atsani, L. (2020). Transformasi Media Pembelajaran Pada Masa Pandemi Covid-19. Jurnal Studi Islam, Vol. 1 No. 1, 84.

Dewi, W. (2020). Dampak Covid - 19 Terhadap Implementasi Pembelajaran Daring Di Sekolah Dasar. Jurnal Ilmu Pendidikan, Vol. 2 No. 1, 56.

Hayati, Y. (2021). Pembelajaran Daring Bervariasi Di Masa Covid - 19 Untuk Meningkatkan

Keaktifan Peserta Didik SMPN 4 MATARAM. Jurnal Inovasi Keguruan dan Ilmu Pendidikan, Vol. 1 No. 1, 40.

Hendriana, H., \& Soemarmo, U. (2017). Penilaian Pembelajaran Matematika. Bandung: PT Refika Aditama.

Husamah, Pantiwati, Y., Restian, A., \& Sumarsono, P. (2018). Belajar dan Pembelajaran. Malang: Universitas Muhammadiyah Malang. 


\section{Sibaitile Jocumal}

Jurnal Ilmiah Bioang Sosial, Tkonomi, Budaya, Tekuologi, dan Pendidikan

Ibrahim, N., \& Purwatiningsih, H. (2019). Perspektif Pendidikan Terbuka Jarak Jauh. Yogyakarta: Media Akademi.

Ika Pratiwi, Amaliyah, A. ., \& Puspita Rini, C. . (2021). ANALISIS KEMAMPUAN BERPIKIR KREATIF MATEMATIS SISWA DALAM MENYELESAIKAN SOAL CERITA DI KELAS IV MI AL-KAMIL KOTA TANGERANG. Berajah Journal, 2(1), 1-5. https://doi.org/10.47353/bj.v2i1.43

Lestari, N., Sudarsana, I., Wijaya, I., Krisdayanthi, A., Andayani, K., \& Trisnadewi, K. (2020). COVID - 19 Perspektif Pendidikan. Yayasan Kita Menulis.

Marlina. (2019). Asesmen Kesulitan Belajar. Jakarta Timur: Prenadamedia Group.

Maryani, I., Fatmawati, L., Erviana, V., Wangid, M., \& Mustadi, A. (2018). Model Intervensi Gangguan Kesulitan Belajar. Yogyakarta: K-Media.

Munir. (2012). Pembelajaran Jarak Jauh. Bandung: Alfabeta.

Nindiawati, D., Subandowo, M., \& Rusmawati, R. (2021). Pengembangan Bahan Ajar Matematika untuk Siswa Kelas V Sekolah Dasar. Jurnal Kajian Teknologi Pendidikan, Vol. 6 No. 1, 141.

Nurjannah, Danial, \& Fitriani. (2019). Diagnostik Kesulitan Belajar Matematika Siswa Sekolah Dasar Pada Materi Operasi Hitung Bilangan Bulat Negatif. Jurnal Kependidikan, 13, No. 1, 68.

Pohan, A. (2020). Konsep Pembelajaran Daring Berbasis Pendekatan Ilmiah. Jawa Tengah: CV Sarnu Untung.

Rahmi, A. (2015). Diagnosis Kesulitan Belajar. Sumatera Barat: P3SDM Melati.

Sugiyono. (2016). Metode Penelitian Kuantitatif, Kualitatif, Dan R\&D. Bandung: Alfabeta.

Susanto, A. (2018). Teori Belajar \& Pembelajaran Di Sekolah Dasar. Jakarta: Prenadamedia Group.

Suyono, \& Hariyanto. (2016). Belajar Dan Pembelajaran. Bandung: PT Remaja Rosdakarya Offset.

Syah, M. (2013). Psikologi Belajar. Jakarta: PT Raja Grafindo Persada.

Widyastuti, A. (2021). Optimalisasi Pembelajaran Jarak Jauh (PJJ), Daring Luring, BDR. Jakarta: PT Elex Media Komputindo.

Yeni, A. (2015). Kesulitan Belajar Matematika Di Sekolah Dasar. JUPENDAS, Vol. 2 No. $2,2$. 
